\title{
Effects of the trawling industrial fishery system on fish community structure on the inner Amazon shelf
}

\author{
Wellington Matheus Gomes de Lima ${ }^{1}{ }^{\circ}$, Walter Hugo Diaz Pinaya ${ }^{2, *} \mathbb{C}^{\circ}$, Ítalo Antônio de Freitas Lutz ${ }^{3}$, Mayra \\ Sousa do Nascimento ${ }^{4}{ }^{\circ}$, Lins Erik Oliveira da Silva ${ }^{5}$, Israel Hidenburgo Aniceto Cintra ${ }^{6}$, Bianca Bentes ${ }^{70}$ \\ ${ }^{1}$ Universidade Federal do Pará - Instituto de Estudos Costeiros (Alameda Leandro Ribeiro S/N - Bairro Aldeia - Bragança - 68600-000 \\ - PA - Brazil) \\ ${ }^{2}$ Mar e Vida ONG (Rua Cabreúva, 154 - Vila Lucinda - Santo André - 09250-710 - SP - Brazil) \\ ${ }^{3}$ Universidade Federal do Pará - Laboratório de Genética Aplicada (Instituto de Estudos Costeiros - Alameda Leandro Ribeiro S/N - \\ Bairro Aldeia - Bragança - 68600-000 - PA - Brazil) \\ ${ }^{4}$ RARE Brasil Organização (Av. Governador José Malcher, 1094 - Bairro Nazaré - CEP: 66055-260, Belém, Pará, Brazil) \\ ${ }^{5}$ Instituto Federal de Educação, Ciência e Tecnologia do Pará - Laboratório de Estudo em Pesca do Nordeste Paraense (BR 316, Km 61 \\ - Bairro Saudade II - Cristo Redentor - Castanhal - 68740-970 - PA - Brazil) \\ ${ }^{6}$ Universidade Federal Rural da Amazônia - Instituto Socioambiental e dos Recursos Hídricos (Avenida Tancredo Neves - Bairro Terra \\ Firme - Belém - 66077-530 - PA - Brazil) \\ ${ }^{7}$ Universidade Federal do Pará - Núcleo de Ecologia Aquática e Pesca da Amazônia (Avenida Perimetral 2651 - Terra Firme - Belém - \\ 66077-530 - PA - Brazil)
}

* Corresponding author: walterpinaya@gmail.com

\section{Abstract}

The present study aims to investigate the variability of catches by trawling fleet vessels licensed to operate under the 'diverse fish' license in relation to the depth gradient and the hydrological cycle of the Amazon River. For this purpose, vessels operating in this category were accompanied by on-board observers on the inner Amazon shelf, during January, April and July 2013 and in April, May, August and September 2014. A total of 115,505 kg of fish was harvested, distributed among 22 species. The flood period was the most representative, with a total of $43,122 \mathrm{~kg}$, followed by the ebb period $(28,749 \mathrm{~kg})$, the rainy period $(23,171 \mathrm{~kg})$ and the dry period $(20,424$ $\mathrm{kg}$ ). Kingfish (Macrodon ancylodon) was the most abundant fish in all seasons (79.7\%). Significant differences were observed in fish composition in relation to the depth gradient and hydrodynamics of the Amazon River, with higher richness and diversity (Margalef index) during flood periods and at greater depths throughout the study period. We also observed a significant interaction between river flow and depth category, with more diversified fish fauna attributed to ebbs and floods in shallow and deep waters at the mouth of the Amazon River. Considering that the license for 'diverse fish' was established as an alternative to fishing for marine shrimp in closed season, the need for effective monitoring of this fishing system is reiterated for an efficient assessment of the impacts in the fish community structure.

Descriptors: Bycatch, Fish diversity, Fishery regulation, Macrodon ancylodon.

\section{INTRODUCTION}

Biological production in inshore fisheries supports more than $90 \%$ of global fish catches (Pauly

Submitted: 12-Nov-2020

Approved: 17-July-2021

Editor: Rubens M. Lopes

Associate Editor: Francesc Maynou

๑ 2021 The authors. This is an open access article distributed under the terms of the Creative Commons license. et al., 2002), generating income, jobs and food security for millions of people (UNEP, 2011). Since the 1960s, trawl fishing has been widely used in the northern coastal region of Brazil and on the inner Amazon shelf, producing a high impact on in this region (Nóbrega et al., 2021). Even so, it continues to have very rich ichthyofauna compared to other tropical regions in the world (Stobutzki et 
al., 2001; Tonks et al., 2008; Nóbrega et al., 2021). Currently, the laulao catfish, Brachyplatystoma vaillantii (Valenciennes, 1940), and the southern brown shrimp, Farfantepenaeus subtilis (Pérez Farfante, 1967), are the main targets of this industry (Isaac et al., 2009; Bentes et al., 2012; Klautau et al., 2016). The industrial fisheries in northern Brazil operate with nets of low selectivity, such as bottom trawls, which retain a significant number of bycatch species (Pinheiro and Frédou, 2004), distributed in 52 taxa of osteichthyes and cartilaginous fish included in 22 families (Jimenez et al., 2013). This problem is especially pronounced in the shrimp fisheries.

Seeking to reduce such an impact, the Brazilian Ministry of Fisheries and Aquaculture (MPA) established a ban season for motorized shrimp trawling through an Interministerial Normative instruction (No. 14, October 31, 2011), which lasted from December 15, 2011 to February 15, 2012. With the ban period of shrimp fishing and to guarantee the continuity of fish production by the fishing industry, it was necessary to create a new category of industrial fishing by the government, known as 'License for bottom trawling for diverse fishes' (IN Interministerial Normative instruction $\mathrm{n}^{\circ} 2$ of January 15, 2010).

The fleet is licensed to operate within an area that extends between the Brazil-French Guiana boundary (demarcated by the rhumb line with a true azimuth of $41^{\circ} 30^{\prime}$, originating at $4^{\circ} 30^{\prime} 30^{\prime \prime} \mathrm{N}, 51^{\circ} 38^{\prime} 12^{\prime \prime} \mathrm{W}$ ) and the Piaui-Ceará Brazilian state boundary region $\left(41^{\circ} 12^{\prime} \mathrm{W}\right)$. This area was subsequently divided into two zones (I and II) through Interministerial Normative Instruction No. 13, September 18, 2013. Currently, the fleet consists of 14 vessels licensed by the MPA for this type of trawling (for 'diverse fishes' on the Amazon continental shelf), which operate throughout the year (Silva et al., 2014). This system is the product of the present management model adopted by the extinct Ministry of Fisheries and Aquaculture (MPA) and the current Ministry of the Environment (MMA), which has based its decisions on discussion in the Commission for Shared Fishery Resource Management Techniques (CTGP). Despite the implementation of the license, little is known of the fishery technique it regulates, and the impacts of this technique on the target species are poorly defined.
The impacts of trawling can be seen in the variation in abundance, richness and trophic structure in the fish community (Fulton et al. 2005), leading to loss of diversity with weakening of ecosystem structure (Buhl-Mortensen et al. 2016). Fishing is known to impact fish communities through the selective removal of the target species, the bycatch of nontarget species, and habitat modifications, resulting in a reduction of total biomass, changes in species composition and the size structure of the populations (Pauly et al., 2003). Trawling tends to provoke a decline in the abundance of large, long-lived fish, such as elasmobranchs, and some other smaller fish (e.g. Mugilidae), and an increase in shrimp and squid (Bianchi et al., 2000).

This high complexity is associated with the defined physical conditions on the Amazon continental shelf, due to: a) the large amount of sediment exported from the Amazon River to the sea and the variability of the Amazon River plume; b) variation of physical parameters such as temperature, salinity, turbulence and mixing layer depth; c) action of trade winds, coastal dynamics and macro tide dynamics (Nittrouer et al. 1986; Geyer et al. 1996; Molleri et al. 2010; Moura et al. 2016). The large volume of freshwater and continental sediments discharged into the inner Amazon platform affects the local action of the tidal regime, oceanic currents and several oceanographic processes, with a direct impact on the composition of biota and regional ecosystems (Marceniuk et al., 2013). Nóbrega et al. (2021), analyzing invertebrate assemblages on the Amazon coast, found that species richness variability is related to temperature, depth and lunar phase. The Amazon shelf stands out for its semidiurnal macrotide and strong tidal currents with great biweekly variability, and tidal amplitudes at the mouth of the Amazon River of more than $3 \mathrm{~m}$ (Perillo et al., 1999; Gibbs, 1982). The tidal cycle influences the interaction of tidal currents and Amazon River discharge on sediment and nutrient transport (Bearsley et al., 1995).

The present study investigated the assemblage structure of fishery resources impacted by the current trawling system with licensed bottom trawlers for 'diverse fish' on the inner Amazon shelf and determined possible correlations of abundance, richness, and diversity with the seasons of Amazon River 
hydrological cycle and depth gradient. This research provides information on changes in fish community structure, showing priorities for future research on the exploitation of species living in the Amazon estuary and inner shelf, aiming at building strategies for mitigating the pressure on these species, especially the most vulnerable.

\section{METHODS}

\section{StUdY AREA}

The coordinates of the study area are $01^{\circ} 11^{\prime} 11^{\prime \prime} \mathrm{N}-00^{\circ} 46^{\prime} 31^{\prime \prime} \mathrm{S}$ of latitude and $49^{\circ} 01^{\prime} 00^{\prime \prime} \mathrm{W}$ - 46.25'59"W of longitude, located on the inner Amazon shelf, close to the Amazon River mouth, corresponding to an area of $67,000 \mathrm{~km}^{2}$ (Fig. 1). This area has a lightly sloping topography. Several physical processes on the inner Amazon shelf and Amazon river hydrologic cycle influence transport, destination of sediments, biotic material and nutrients on the inner Amazon shelf. The Amazon River plume has an anomalous dynamical behavior (Lentz, 1995a). The Amazonian inner shelf area is influenced by the discharge of the Amazon River, which has the largest freshwater discharge in the world (Masson and Delecluse 2001). The hydrography of the Amazonian shelf is dominated by a surface plume water formed as freshwater from the Amazon River mixes with high salinity adjacent ocean water (Geyer et al., 1991; Castro et al., 2006). The Amazon River plume has an anomalous behavior and extends for $1000 \mathrm{~km}$ northwest of the North Atlantic and spreads eastward 200-300 $\mathrm{km}$ from June to December and 400-500 km from March to May, when the river reaches its highest freshwater discharge (Gibbs, 1970; Muller-Karger et al., 1988; Lentz, 1995b).

The predominant wind in the region are the tradewinds, and the local wind stress along the coast is the conditioning factor of subtidal current variability (Lentz, 1995b). The maximum wind stress occurs from December to April and influences the flow of the Amazon River water and sediment over the shelf (Lentz, 1995b; Aller and Stupakoff, 1996). In addition to the large freshwater input, high of amounts sediment are discharged from the river and deposited as fluid mud on the inner Amazon shelf. The mud extends along the coast to the northwest, covering extensive areas of the inner and middle Amazon shelf (Geyer et al., 1996; Kineke and Sternberg, 1995). Changes in freshwater

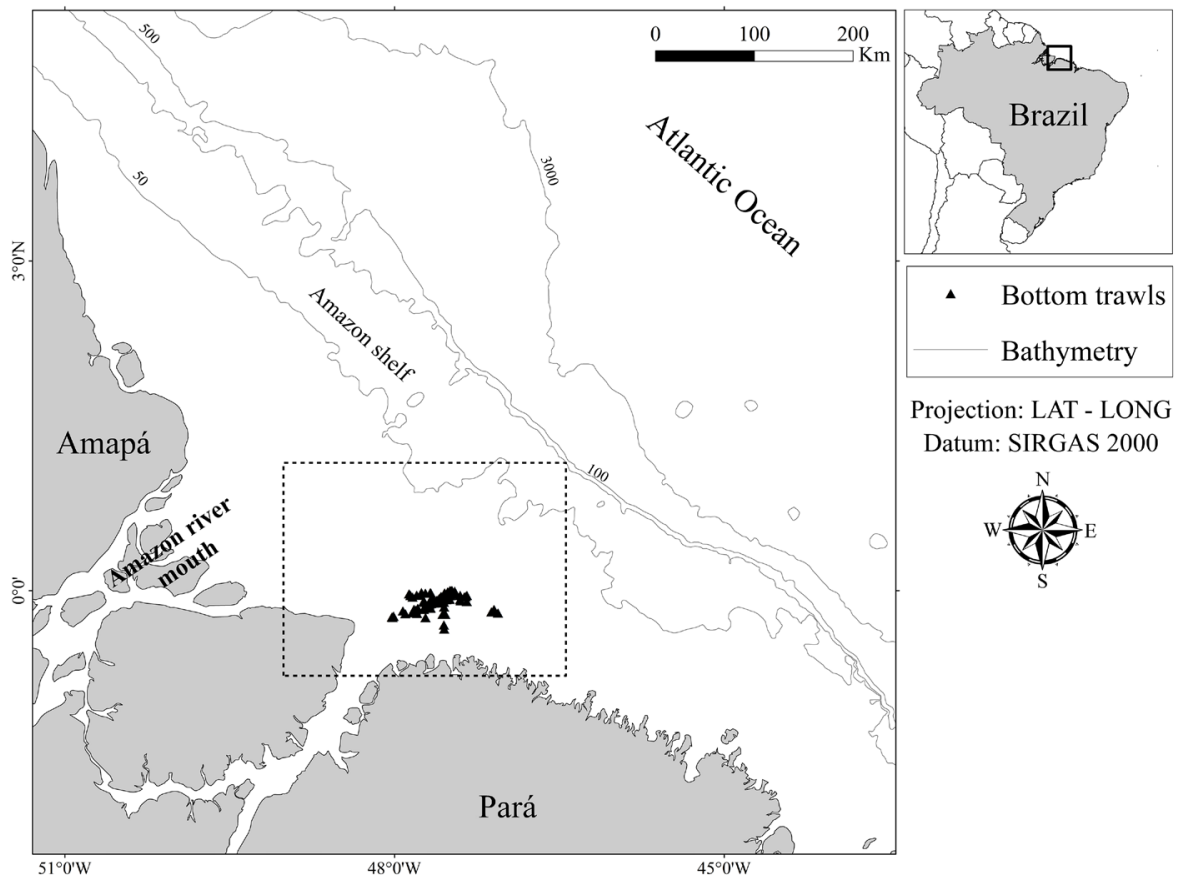

Figure1. Operational area of the industrial trawler fleet in the inner Amazon shelf. The triangles indicate the georeferenced sites at which data were collected on board vessels of the industrial fleet operating with bottom trawls. 
content and transport on the inner Amazon shelf affect water affect water residence time in the Amazon estuary (Geyer et al., 1991).

Along the mouth of the Amazon River, the salinity structure resembles an estuarine saline wedge that is not confined laterally to a river channel, as in typical salt wedge estuaries. Salinity variations represent changes of the first order in the total freshwater content of the shelf on much shorter time scales than the seasonal variability in the river flow. Also, semi-diurnal macro tides produce the strongest currents over the shelf, which can reach speeds of $200 \mathrm{~cm} \mathrm{~s}^{-1}$ in the surface waters of the frontal zone, between river and ocean water (Beardsiey et al., 1995). Near-bottom subtidal flow is considerably weaker $\left(0-20 \mathrm{~cm} \mathrm{~s}^{-1}\right)$ and variable (Lentz, 1995b; Geyer and Kineke, 1994).

\section{SAMPLeS}

Data were collected by observers aboard vessels licensed to capture a diversity of fish species on the Amazon continental shelf in January, April and July 2013 and April, May, August and September 2014, by the Northern Biodiversity Research and Conservation Center (CEPNOR / ICMBio), with a total of 227 fishing hauls (Table 1). While on board, observers collected data on fishing operations and catch composition, including records of the haul date, depth, zone, route, duration, latitude and longitude, start and end of each haul, the common name of the species, and the volume of catch and bycatch. The diversity of fish was verified after emptying the nets on the boat decks. The sampling unit used was the trawl and they were tested between seasons and depth classes.

\section{Data PROCEssing}

Species identification was based on the comparison of specimens collected in situ with specialized studies (Cervigón et al., 1993; Figueiredo and Menezes, 2000; Szpilman, 2000). The data were compiled in spreadsheets, organized by depth class, with four classes: DC 1 (20-25 m), DC 2 (25-30 m), DC 3 (30-35 m), and DC 4 (35-40 m). To determine the depth class, it was assumed that there was no record for any depth shallower than $20 \mathrm{~m}$ or deeper than 40 $\mathrm{m}$, based on the local knowledge of bottom trawlers.

\section{Analysis}

Species richness $(S)$ is the number of species in a community. Ecological diversity was assessed using the Margalef (d) index. The Margalef index estimates the numerical distribution of individuals of different species as a function of the total number of individuals in the sample. Diversity includes equitability associated with species richness. As our sampling design was explicitly unbalanced, because the hauls were made through the authorized commercial fleet, a "Permutational Multivariate Analysis of Variance" (PERMANOVA; Anderson, 2001; Anderson et al., 2008) was used to test for variation in the composition of the fish assemblage among the different depth zones and discharge categories of the Amazon River (drought, wet, flood, and ebb). The statistical significance of this analysis was tested using 9999 permutations of the residuals in a reduced model and Type III (partial) sums of squares (SS; Anderson et al., 2008). The PERMANOVA were run using a Bray-Curtis similarity matrix calculated for the fourth root transformed catch data. Significant $(p<0.05)$ differences in river discharge and depth were investigated further using Multidimensional Scaling Analysis (MDS; Anderson

Table 1. Year, month, number of hauls and trawling time in hours by the industrial fishery fleets that operate in the inner Amazon shelf.

\begin{tabular}{ccccc}
\hline Year & Month & Number of hauls & Trawling time (h) \\
\hline 2013 & January & 63 & 125.6 \\
2013 & April & 34 & 40.5 \\
2013 & July & 27 & 55.3 \\
2014 & April & 34 & 69.0 \\
2014 & May & 20 & 40.5 \\
2014 & August & 19 & 42.5 \\
2014 & & 30 & 61.5 \\
\hline
\end{tabular}


and Willis, 2003). To assess the distribution of species among the river discharge and depth, a shade plot was produced by clustering the samples on the $x$-axis based on Bray-Curtis similarity. Statistical analyses were run in PRIMER version 7.0.11 with the PERMANOVA+ add-on (Anderson et al., 2008; Clarke et al., 2014; Clarke and Gorley, 2015).

\section{RESULTS}

A total of $115,505 \mathrm{~kg}$ of fish was harvested, distributed among 22 species (Table 2). The Amazon river flood season returned the largest catch, with a total of $43,122 \mathrm{~kg}$, followed by the ebb period $(28,749 \mathrm{~kg})$, wet period $(23,171 \mathrm{~kg})$ and the dry season $(20,424$ $\mathrm{kg}$ ). The king weakfish (Macrodon ancylodon) was the most abundant fish in all seasons $(79.7 \%$ of the total biomass captured). The second most abundant species in the dry season was Cynoscion virescens, while Bagre bagre was the second most abundant in the flood, Plagioscion surinamensis in the ebb and Aspistor quadriscutis in the wet period. The Elasmobranchs (sharks and rays) of the families Carcharhinidae and Dasyatidae accounted for less than $0.5 \%$ of the total catch. Shark were caught in all seasons, the highest percentage biomass was recorded in the wet season, while the ray catch was highest at the ebb river period. Some species, such as Lutjanus sinagris were caught only at the beginning of the flood season. Others such as Chaetodipterus faber were caught in the flood and dry seasons. Grey mullets (Mugilidae), by contrast, were mainly caught in the wet season, with less catch in the flood period (Table 2). Richness, the Margalef index (diversity) and biomass were higher in the flood periods and at greater depths throughout the study period (Table 3 ).

Multivariate PERMANOVA revealed significant differences in the composition of the fish assemblages ( $p<0.001$ ) among the four river discharge seasons (Table 4). Pairwise comparisons across depth levels revealed subtle (graphical) differences in the fish assemblage composition between depths, whilst across the Amazon river discharge all fish assemblage compositions differed significantly in multivariate pairwise comparisons (most with $\mathrm{P}<0.01$ ). There was significant interaction for river discharge vs. depth category (Table 4) with more diversified fish fauna assigned to ebb and flood located in shallow and deep water in Amazon river mouth (Fig. 2).
Different species, even within the same family, presented varying degrees of 'habitat' partitioning, considering the factors tested (Fig. 2). In the case of the Ariidae and Sciaenidae, for example, Sciades quadriscutis, Sciades grandicassis and Bagre bagre were most often associated with the wet season in all depth categories, while Plagioscion magdalenae and Cynoscion acoupa were associated predominantly with transitional periods from CP2 to CP4. In contrast, Macrodon ancylodon was captured in all seasonal periods and depths. The shade plot that combines the two cluster analyses of the fish assemblage data identified three separate groups (top dendrogram) and three principal groups (left dendrogram) of fish taxa with similar season and depth associations (Fig. 2).

Habitat arrangement in the multivariate space clearly revealed a separation along the MDS1 and MDS2 axis, into river discharge seasons (Fig. 3). Moreover, the MDS ordination indicated that the dry season hosted a distinct assemblage of marine fishes, isolated with little overlap with the flood period. A similar, but less exclusive grouping was formed by the transitional seasons (flood and ebb).

\section{DISCUSSION}

Kelleher (2005) estimated that approximately seven million tons of bycatch are discarded per year by fisheries around the world. Considering marine and estuarine fisheries in the northern Brazilian coastal region, it was estimated that more than 30 thousand tons of bycatch/year are discarded, mainly in trawl fisheries (Isaac, 1998). The practice of nonselective fisheries, such as bottom trawling, leads to the accidental bycatch of juvenile individuals and endangered species of commercial and ecological relevance (Alverson et al., 1994; Kenelly, 1995; Lewison et al., 2004; Jimenez et al., 2013). This may modify the composition and structure of these populations, with loss of biodiversity (Lewison et al., 2004; Stobutski et al., 2003), especially in ecologically sensitive species (Hall et al., 2000; Hall and Mainprize, 2005; Jimenez et al. 2016; Nóbrega et al., 2021). Industrial bottom trawl fishing on the north coast of Brazil has been operating continuously for a long time.

The Amazon River, being a saline wedge-type estuary outside the mouth of the river, is subject to environment modifications according to the phases of 


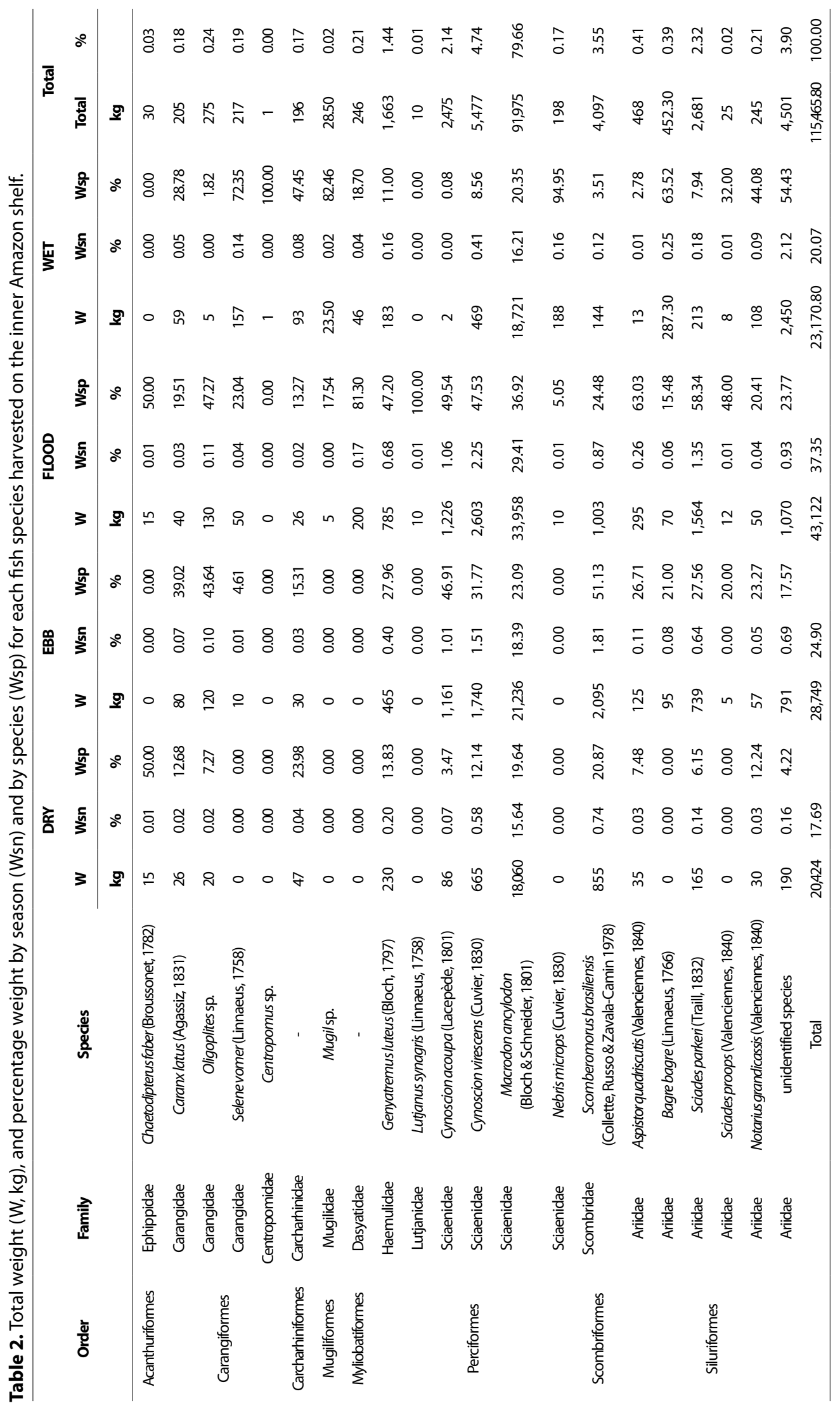


Table 3. Details of fish catches recorded during the period analyzed considering the Amazon River seasons (flood, wet, ebb and dry), depth classes (CP) and richness (S), biomass kg and Margalef diversity index (d)). CP1 = $20-25 \mathrm{~m}$; CP2 = $25-30 \mathrm{~m} ; \mathrm{CP} 3=30-35 \mathrm{~m} ; \mathrm{CP} 4=35-40 \mathrm{~m}$.

\begin{tabular}{|c|c|c|c|c|}
\hline Amazon River season & Depth & $\mathbf{S}$ & Biomass (kg) & d \\
\hline \multirow{4}{*}{ FLOOD } & $\mathrm{CP} 1$ & 0 & 0 & 0 \\
\hline & $\mathrm{CP} 2$ & 14 & 2,872 & 1.63 \\
\hline & $\mathrm{CP} 3$ & 14 & 12,246 & 1.38 \\
\hline & $\mathrm{CP} 4$ & 22 & 28,908 & 2.04 \\
\hline \multirow{4}{*}{ WET } & $\mathrm{CP} 1$ & 10 & 1,160 & 1.28 \\
\hline & $\mathrm{CP} 2$ & 14 & 3,304 & 1.60 \\
\hline & $\mathrm{CP} 3$ & 22 & $8,071.80$ & 2.33 \\
\hline & $\mathrm{CP} 4$ & 17 & 10,890 & 1.72 \\
\hline \multirow{4}{*}{ EBB } & $\mathrm{CP} 1$ & 15 & 6,243 & 1.60 \\
\hline & $\mathrm{CP} 2$ & 14 & 8,603 & 1.43 \\
\hline & $\mathrm{CP} 3$ & 9 & 10,466 & 0.86 \\
\hline & $\mathrm{CP} 4$ & 12 & 3,463 & 1.35 \\
\hline \multirow{4}{*}{ DRY } & $\mathrm{CP} 1$ & 0 & 0 & 0 \\
\hline & $\mathrm{CP} 2$ & 0 & 0 & 0 \\
\hline & $\mathrm{CP} 3$ & 12 & 15,419 & 1.14 \\
\hline & CP4 & 10 & 5,005 & 1.06 \\
\hline
\end{tabular}

Table 4. PERMANOVA results of the fish species composition caught out in the Amazon shelf according to season (SE), depth (DE) and the interaction between season and depth (SE x DE). df: degrees of freedom, SS: sum of squares, MS: mean of squares, $\mathrm{P}$ (perm): probability.

\begin{tabular}{ccccccc}
\hline Source & df & SS & MS & Pseudo-F & P(perm) & Unique perms \\
\hline SE & 3 & $37,976.00$ & $12,659.00$ & 11.13 & 0.00 & 9,998 \\
DE & 3 & $3,149.30$ & $1,049.80$ & 15.41 & 0.07 & 9,998 \\
SE x DE & 6 & $7,348.30$ & $1,224.70$ & 1.80 & 0.07 & 9,998 \\
Residual & 214 & $1.46 \mathrm{E}+05$ & 681.14 & & & \\
Total & 226 & $2.11 \mathrm{E}+05$ & & & & \\
\hline
\end{tabular}

the hydrological cycle. Large amounts of sediments and organic and inorganic particles are frequently released onto the inner Amazon shelf. The saline wedge exports freshwater at the surface of the inner Amazon shelf, with an intermediate layer of fresh-salt water mixture and a salt layer near the bottom. The variability of turbulent local processes also contributes to the distribution of fisheries resources. Each species has an optimal environment of salinity, temperature and turbulence for the survival and development. In wet and flood seasons, with increased freshwater discharge and expansion of the Amazon River estuary, freshwater species tend to reach coastal areas. In the dry season, the Amazon River estuary retracts, with a consequent increase in salinity, allowing marine species to occur in the inner estuarine region (Barthem,
1985; Jimenez, 2013), as also observed in this study. Our results are compatible with the main target species caught with the "diverse fishes" fishing license given to the fishing vessels of the bottom trawl fleet operating in the inner Amazon shelf. Species with greater tolerance for environmental variability, such as Macrodon ancylodon, tend to be present throughout the year in the catches.

The industrial fishery system analyzed in the present study raises important questions on the non-selectivity of the fishing gear, and the direct or indirect effects this may have on the structure of the biological community. Bottom trawling can lead to overfishing because it is not selective and discards too many dead fish. Overfishing by bottom trawls is a direct threat to local fishing communities, decreasing 


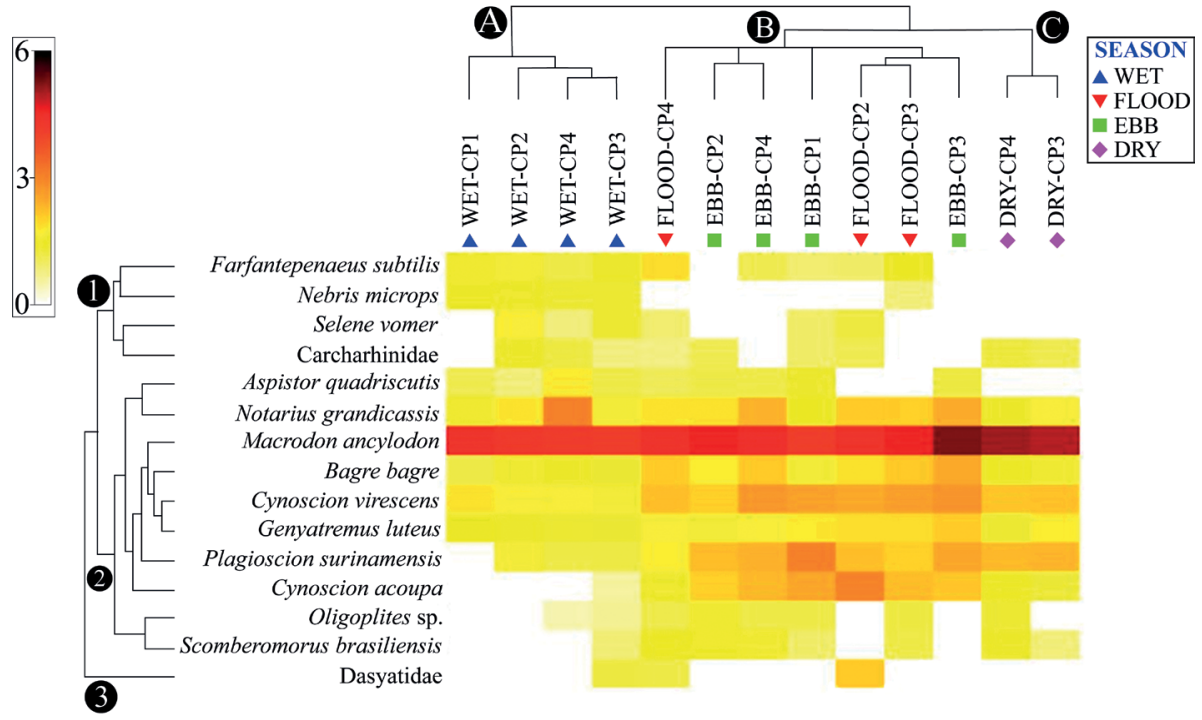

Figure 2. Shade plot of the distribution of fish species landed by license for diverse fishery in mouth of the Amazon River among the four groups of discharge (top dendrogram), showing the three groups (left cluster) of the fish species and their depth category association. The color gradient from dark (strong correlation) to soft yellow (weak correlation) indicates the strength of species season and depth association.

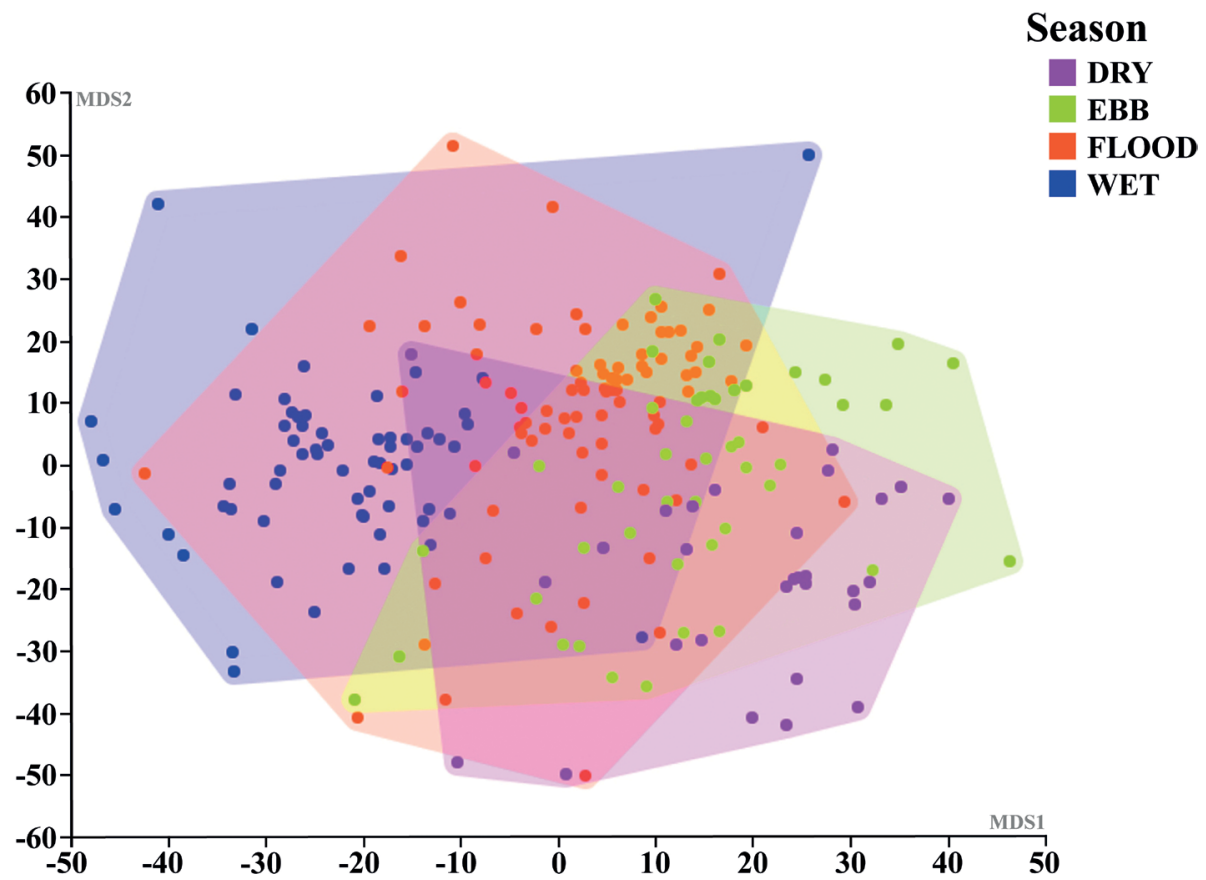

Figure 3. Multidimensional scaling biplot and comparing the structure of fish communities on landed by license for diverse fishery in mouth of the Amazon River among the four groups of river discharge.

the abundance of adult species and reducing the potential for population recruitment (Stiles et al., 2010). In Indonesia, for example, a $40 \%$ decrease in local catches was observed after the expansion of bottom trawling (JALA, 2020).
Even without knowing the ecological indices of this fishery system, some taxa disappeared from recent inventories. Some examples are Anchoa hepsetus, Anchoviella lepidentostole, Antigonia sp., Arius (Sciades) phrygiatus, Citharichthys spilopterus, 
Dasyatis guttata; Gymnura micrura, Sphyrna lewini, among others (Maia et al., 2016; Passos et al., 2016). Marceniuk et al. (2013) concluded that most studies in northern Brazil have focused primarily on a small number of commercially important species (AsanoFilho et al., 2005; Frédou and Asano-Filho, 2006). The implementation of a ban season for $F$. subtilis, the primary target species of the trawl fisheries on the inner Amazon shelf, led to the pressuring of the federal government by the fishery sector to guarantee avoiding any loss of productivity during this period. The target fish species caught with the current fishery system are influenced by the hydrodynamics of shallow waters in the inner Amazon shelf and the Amazon River discharge.

More than half the total fishing production by the system was made up of a single species, Macrodon ancylodon, which was captured in relatively large amounts throughout the four seasons. Espírito-Santo and Isaac (2012) recorded a similar predominance of M. ancylodon in their analysis of fishery in northern Brazil, where this species was among the most common fishes landed by both coastal and estuarine fisheries from 2000 onwards. Macrodon ancylodon was the most abundant fish in the whole hydrological cycle of the Amazon River during the period analyzed. It is found on mud or sandy mud bottoms in coastal waters preferably at a depth of 25 m (Cervigón, 1993). It is a demersal species and supports high variations in salinity that allows it to be caught throughout the year, as verified in our analyses. Willems et al. (2015a) studied fish assemblages in the Suriname coastal region and observed three classes related to the depth gradient. The first group was formed by coastal fish in shallow waters and muddy sediments, dominated by Sciaenidae and Ariidae. The second assemblage was a transitional assemblage at around $27 \mathrm{~m}$ depth with muddy substrate and characterized by a demersal fish community, in a transition zone between the coastal ecosystem and the offshore continental shelf. The third assemblage was composed of different offshore fish, in sites deeper than $34 \mathrm{~m}$, with thick sediments and overlying clear water, characterized by the absence of Sciaenidae and representatives of typical fish families from deeper tropical continental shelves, such as Paralichthyidae, Triglidae and Lutjanidae. This environmental change in depth of transition has also been observed in Guyana (Lowe-McConnell, 1962) and French Guiana (Vendeville and Baudrier, 2006). Little temporal variation was detected in the fish community, despite the clear seasonality in several environmental parameters during the study, such as total suspended matter concentration below the surface and chlorophyll concentration during the rainy season (Willems et al., 2015b).

The second most abundant fish species in each Amazon River hydrological period are related to their life history, and the position of the estuarine salt wedge on the inner Amazon shelf. Cynoscion virescens was the second most caught in the dry period, when adults stay in the sandy mud substrate during the day and swim to the surface at night (Keith et al. 2000). During this period there is a retraction of the saline wedge and the waters adjacent to the Amazon River mouth become brackish. During the flood period of the Amazon River, there is an abundance of food and Bagre bagre was the second most caught in that season. It is an endemic species with distribution from Colombia to the mouth of the Amazon River. During the flood period, the Amazon River estuary enlarges, i.e., the saline wedge expands the most, bringing freshwater to the inner Amazon shelf. Plagioscion surinamensis is a benthopelagic species and most caught in the period. This species is endemic to Suriname and the Amazon regions, with preferences ranging from fresh to brackish water. It lives mainly in estuaries and at an average depth of $30 \mathrm{~m}$. When, the estuarine saline wedge retracts and starts to get closer to the mouth of the Amazon River and, this species takes the opportunity to feed on smaller fish as it finds favorable environmental conditions. Found in turbid waters over muddy bottoms in shallow coastal areas, also around estuaries (Taylor and Menezes, 1978) and coastal rivers (Marcenik and Farias, 2003), Sciades quadriscutis was the second largest caught in the wet period. It is a benthopelagic species and inhabits all salinity ranges.

The current fishery system may also have an important impact on a number of other species, in particular those with low ecological resistance, such as sharks and rays Despite accounting for only $0.4 \%$ of the total harvest, elasmobranchs include a number of ecologically vulnerable species, which are typical $k$ strategists due to their low fertility, slow growth and long-life cycle (Compagno, 1984; Camhi et al., 1998), and are mostly discarded overboard as dead bycatch. 
Carcharhinids are found mainly in oceanic waters, although some species inhabit fresh or brackish water, and their populations may also be impacted through bycatch along the year. These species are more vulnerable in the dry and humid periods, when the Amazon River discharge is weaker, and the estuary interface approaches the river mouth. Other ecologically vulnerable species are the rays that occur mainly in shallow coastal waters, lagoons, and estuaries. They are benthic species and often remain partially buried in soft muddy bottom substrates (Carpenter and Niem, 1999). In this research, we verified that they are more captured in the flood and wet phases of the Amazon River, when a high load of fluid mud reaches the region where the bottom trawl fleet operates on the inner Amazon shelf.

The potential cascade effect of this process could only be evaluated systematically once the complexity, ecological maturity, energy flow and functional diversity of the estuarine and coastal ecosystems in which these fisheries operate, are more fully understood (Castro et al., 2015; Martins et al., 2018). The local knowledge of the fishermen of the bottom trawl fleet must be considered to evaluate fishing production in a given period of the year. During periods of wet and flood in the Amazon River, the estuarine zone expands and estuarine and freshwater species occur in the fishing ground. Regardless of the seasonal or hydrological period of the Amazon River, local fishermen direct their fishing towards the target species Macrodon ancylodon and other economically important species, for example, other hake, croakers, and catfish. The so-called "fishing opportunity" occurs, with a certain target species of economic value, so the most abundant resource is exploited at a given time. The species to be fished will reflect the effort used, directed to a specific depth according to their movement and biology.

Many mitigation strategies can be used in the search for a sustainable fishing activity. One of these alternatives was proposed by Hall (1999) with the prohibition of fishing in some places and times of the year. This measure aims to protect the environments used during the most vulnerable phases of the life cycle of the target species. Although trawling is prohibited in the Amazon and Pará estuaries, the measure seems to be ineffective for the protection of small individuals, as a large part of the bycatch is composed of juveniles (Jimenez et al., 2013). These authors suggest an expansion of the forbidden zone during the dry season, when juveniles are more vulnerable. However, any determination of mitigation measures must be taken in a participatory manner with all actors involved, fishermen, policy makers, government and the fishing industry. Given all these considerations, studies based on estimates of changes in biomass flux (Carrier and Opitz, 1999; Wolff et al., 2000; Rybarczyk and Elkaïm, 2003; Arias-González et al., 2004; Oliveira et al., 2007; Nascimento et al., 2009 ; Villar et al., 2013), associated with the predictions of the support capacity of fishing systems, will be fundamental for the maintenance of productivity levels in the long term.

\section{ACKNOWLEDGMENTS}

We acknowledge the Northern Biodiversity Research and Conservation Center (CEPNOR / Brazil), the Institute of Coastal Studies (IECOS / UFPA), the Fisheries Biotechnology Laboratory for supporting the research in various ways. In addition, we are grateful for the postgraduate programs, the Postgraduate Program in Environmental Biology (PPGBA / UFPA Campus Bragança) and the Postgraduate Program in Aquaculture and Tropical Water Resources in the person of Prof. Dr. Nuno Filipe Melo for academic support. We would also like to thank Dr. Stephen Ferrari for the English translation service.

\section{AUTHOR CONTRIBUTIONS}

W.L.: Conceptualization, Data curation, Investigation, Visualization, Writing - original draft \& Writing review \& editing;

W.P.: Methodology, Formal Analysis, Investigation, Software \& Writing - review \& editing;

I.L.: Data curation, Investigation, Writing - original draft \& Writing - review \& editing;

M.N.: Data curation and Software;

L.S.: Data curation;

I.C.: Project administration, Validation \& Visualization;

B.B.: Conceptualization, Methodology, Formal Analysis, Funding acquisition, Investigation, Supervision, Validation, Resources \& Writing - review \& editing. 


\section{REFERENCES}

ALLER, J. Y. \& STUPAKOFF, I. 1996. The distribution and seasonal characteristics of benthic communities on the Amazon shelf as indicators of physical processes. Continental Shelf Research, 16(5-6), 717-751, DOI: https://doi.org/10.1016/02784343(96)88778-4

ALVERSON, D. L., FREEBERG, M. H., MURAWSKI, S. A. \& POPE, J. G. 1994. A global assessment of fisheries bycatch and discards. FAO Fisheries Technical Paper, 339.

ANDERSON, M. J. 2001. Permutation tests for univariate or multivariate analysis of variance and regression. Canadian Journal of Fisheries and Aquatic Sciences, 58(3), 626-639, DOI: https://doi.org/10.1139/f01-004

ANDERSON, M. J., GORLEY, R. N. \& CLARKE, K. R. 2008. PERMANOVA+ for PRIMER. Guide to Software and Statistical Methods. Plymouth: PRIMER-E.

ANDERSON, M. J. \& WILLIS, T. J. 2003. Canonical analysis of principal coordinates: a useful method of constrained ordination for ecology. Ecology, 84(2), 511-525, DOI: https://doi. org/10.1890/0012-9658(2003)084[0511:CAOPCA]2.0.CO;2

ARIAS-GONZÁLEZ, J. E., NUÑEZ-LARA, E., GONZÁLEZ-SALAS, C. \& GALZIN, R. 2004. Trophic models for investigation of fishing effect on coral reef ecosystems. Ecological Modelling, 172(2-4), 197-212, DOI: https://doi.org/10.1016/j.ecolmodel.2003.09.007

ASANO-FILHO, M., HOLANDA, F. C. A. F., SANTOS, F. J. S. \& CAVALCANTE JUNIOR, T. S. 2005. Recursos pesqueiros de grandes profundidades na costa Norte do Brasil. Brasília: IBAMA (Instituto Brasileiro do Meio Ambiente e dos Recursos Naturais Renováveis).

BARTHEM, R. B. 1985. Ocorrência, distribuição e biologia dos peixes da Baía de Marajó, estuário amazônico. Museu Paraense Emílio Goeldi: Série Zoologia, 2(1), 49-69.

BEARDSLEY, R. C., CANDELA, J., LIMEBURNER, R., GEYER, W. R., LENTZ, S. J., CASTRO, B. M., CACCHIONE, D. \& CARNEIRO, N. 1995. The $M_{2}$ tide on the Amazon shelf. Journal of Geophysical Research: Oceans, 100(C2), 2283-2319, DOI: https://doi. org/10.1029/94JC01688

BENTES, B., ISAAC, V. J., ESPÍRITO-SANTO, R. V. D., FRÉDOU, T., ALMEIDA, M. C., MOURÃO, K. R. M. \& FRÉDOU, F. L. 2012. Multidisciplinary approach to identification of fishery production systems on the northern coast of Brazil. Biota Neotropica, 12(1), 81-92, DOI: https://doi.org/10.1590/S167606032012000100006

BIANCHI, G., GISLASON, H., GRAHAM, K., HILL, L., JIN, X., KORANTENG, K., MANICKCHAND-HEILEMAN, S., PAYÁ, I., SAINSBURY, K., SANCHEZ, F. \& ZWANENBURG, K. 2000. Impact of fishing on size composition and diversity of demersal fish communities. ICES Journal of Marine Science, 57(3), 558-571, DOI: https://doi.org/10.1006/jmsc.2000.0727

BUHL-MORTENSEN, L., ELLINGSEN, K. E., BUHL-MORTENSEN, P., SKAAR, K. L. \& GONZALEZ-MIRELIS, G. 2016. Trawling disturbance on megabenthos and sediment in the Barents Sea: chronic effects on density, diversity, and composition. ICES Journal of Marine Science, 73(Suppl 1), i98-i114, DOI: https:// doi.org/10.1093/icesjms/fsv200

CAMHI, M., FOWLER, S., MUSICK, J., BRÄUTIGAM, A. \& FORDHAM, S. 1998. Sharks and their relatives, ecology and conservation. Occasional Papers of the IUCN Species Survival Commission, 1(20), 1-63.
CARPENTER, K. E. \& NIEM, V. H. 1999. FAO species identification guide for fishery purposes. The living marine resources of the Western Central Pacific. Vol. 4. Bony fishes part 2 (Mugilidae to (arangidae). Rome: FAO Fisheries Department.

CARRER, S. \& OPITZ, S. 1999. Trophic network of a shallow water area in the northern part of the Lagoon of Venice. Ecological Modelling, 124(2-3), 193-219, DOI: https://doi.org/10.1016/ S0304-3800(99)00161-1

CASTRO, B. M., BRANDINI, F. P., PIRES-VANIN, A. M. S. \& MIRANDA, L. B. 2006. Multidisciplinary oceanographic processes on the Western Atlantic continental shelf between $4^{\circ} \mathrm{N}$ and $34^{\circ} \mathrm{S}$. In: ROBINSON, A. R. \& BRINK, K. (eds.). The Sea, Vol. 14 - The global coastal ocean: interdisciplinary regional studies and Syntheses. Cambridge: University of Havard Press.

CASTRO, D. N., LIMA, W. M. G., MENDES, N. C. B., NASCIMENTO, M. S., LUTZ, I. A. F., CARDOSO, C. N. A. \& BENTES, B. S. 2015. Dieta natural de Macrodon ancylodon (Bloch \& Schneider, 1801) capturada por embarcações pesqueiras industriais sediadas no Estado do Pará. Biota Amazônia, 5(3), 50-54, DOI: http://dx.doi. org/10.18561/2179-5746/biotaamazonia.v5n3p50-54

CERVIGÓN, F., CIPRIANI, R., FISHER, W., GARIBALDI, L., HENDRICKX, M., LEMUS, A. J., MÁRQUEZ, R., POUTIERS, J. M., ROBAINA, G. \& RODRIGUEZ, B. 1993. Field guide to the commercial marine and brackish-water resources of the northern coast of South America. Rome: FAO.

CLARKE, K. R. \& GORLEY, R. N. 2015. PRIMER v5, v6 \& v7: user manual/tutorial. Plymouth: PRIMER-E.

CLARKE, K. R., GORLEY, R. N., SOMERFIELD, P. J. \& WARWICK, R. M. 2014. Change in marine communities: an approach to statistical analysis and interpretation [online]. Plymouth: PRIMER-E Ltd. Available at: http://plymsea.ac.uk/id/eprint/7656 [Accessed: 15 May 2019].

COMPAGNO, L. J.V. 1984. Sharks of the world. An annotated and illustrated catalogue of shark species known to date. Part 2 - Carcharhiniformes. FAO Fisheries Synopsis, 125(4-2), 251-655.

ESPÍRITO-SANTO, R. V. \& ISAAC, V. I. 2012. Desembarques da pesca de pequena escala do município de Bragança - PA, Brasil: esforço e produção. Boletim do Laboratório de Hidrobiologia, 25(1), 31-48.

FIGUEIREDO, J. L. \& MENEZES, N. A. 2000. Manual de peixes marinhos do sudeste do Brasil. São Paulo: Museu de Zoologia - Universidade de São Paulo.

FRÉDOU, F. L. \& ASANO-FILHO, M. 2006. Recursos pesqueiros da região norte. In: Capítulo 3 - Avaliação do Potencial Sustentável de Recursos Vivos na Zona Econômica Exclusiva, Relatório Executivo, Programa REVIZEE. Brasília: IBAMA (Instituto Brasileiro do Meio Ambiente e dos Recursos Naturais Renováveis), pp. 127-158.

FULTON, E. A., SMITH, A. D. \& PUNT, A. E. 2005. Which ecological indicators can robustly detect effects of fishing?. ICES Journal of Marine Science, 62(3), 540-551.

GEYER, W. R., BEARDSLEY, R. C., CANDELA, J., CASTRO, B. M., LEGECKIS, R. V., LENTZ, S. J., LIMEBURNER, R., MIRANDA, L. B. \& TROWBRIDGE, J. H. 1991. The physical oceanography of the Amazon outflow. Oceanography, 4(1), 8-14.

GEYER, W. R., BEARDSLEY, R. C., LENTZ, S. J., CANDELA, J., LIMEBURNER, R., JOHNS, W. E., CASTRO, B. M. \& SOARES, I. D. 1996. Physical oceanography of the Amazon shelf. Continental Shelf Research, 16(5-6), 575-616, DOI: https://doi. org/10.1016/0278-4343(95)00051-8 
GEYER, W. R. \& KINEKE, G. C. 1994. Observations of currents and water properties in the Amazon frontal zone. Journal of Geophysical Research: Oceans, 100(C2), 2321-2339, DOI: https://doi.org/10.1029/94JC02657

GIBBS, R. J. 1970. Circulation in the Amazon River estuary and adjacent Atlantic Ocean. Journal of Marine Research, 28(2), 113-123.

GIBBS, R. J. 1982. Currents on the shelf of North-Eastern south America. Estuarine, Coastal and Shelf Science, 14(3), 283-299.

HALL, M. A., ALVERSON, D. L. \& METUZALS, K. I. 2000. By-catch: problems and solutions. Marine Pollution Bulletin, 41(1-6), 204-219, DOI: https://doi.org/10.1016/S0025$-326 \mathrm{X}(00) 00111-9$

HALL, S. J. \& MAINPRIZE, B. M. 2005. Managing by-catch and discards: how much progress are we making and how can we do better?. Fish and Fisheries, 6(2), 134-155, DOI: https://doi. org/10.1111/j.1467-2979.2005.00183.x

ISAAC, V. J. 1998. Fisheries by-catch in the northern coast of Brazil: an anthology of waste. In: CLUCAS, I. \& TEUTSCHER, F. (orgs.). Report and proceedings of FAO/DFID expert consultation on bycatch utilization in tropical fisheries. United Kingdom: FAO/DFID Expert Consultation.

ISAAC, V. J., SANTO, R. V. E., BENTES, B., FRÉDOU, F. L., MOURAO, K. R. M. \& FRÉDOU, T. 2009. An interdisciplinary evaluation of fishery production systems off the state of Pará in North Brazil. Journal of Applied Ichthyology, 25(3), 244-255, DOI: https://doi.org/10.1111/j.1439-0426.2009.01274.x

JALA (Advocacy Network for Fisherfolk North Sumatra). Fisherfolk in cooperation with the Environmental Justice Foundation. When fishing turns deadly: the environmental and social impacts of illegal trawling in North Sumatra [online]. Sumatra: JALA. Available at: http://www.magisterseniusu.com/ uploads/1/8/0/0/1800340/jala_\%E2\%80\%93_the_advocacy_network_for_north_sumatra_fisherfolk-the_environmental_and_social_impacts_of_illegal_trawling_in_north_sumatra.pdf [Accessed: 20 April 2020].

JIMENEZ, E. A., ASANO FILHO, M. \& FRÉDOU, F. L. 2013. Fish bycatch of the laulao catfish Brachyplatystoma vaillantii (Valenciennes, 1840) trawl fishery in the Amazon Estuary. Brazilian Journal of Oceanography, 61(2), 129-140.

JIMENEZ, H., DUMAS, P., MOUILLOT, D., BIGOT, L. \& FERRARIS, J. 2016. Harvesting effects on functional structure and composition of tropical invertebrate assemblages. ICES Journal of Marine Science, 73(2), 420-428, DOI: https://doi. org/10.1093/icesjms/fsv179

KEITH, P., LE BAIL, P. Y. \& PLANQUETTE, P. 2000. Atlas des poissons d'eau douce de Guyane. Tome 2, Fascicule I: Batrachoidiformes, Mugiliformes, Beloniformes, Cyprinodontiformes, Synbranchiformes, Perciformes, Pleuronectiformes, Tetraodontiformes. Paris: Publications scientifiques du Muséum national d'Histoire naturelle.

KELLEHER, K. 2005. Discards in the world's marine fisheries: an update. Rome: FAO Fisheries Technical Paper.

KENELLY, S.J. 1995. The issue of bycatch in Australia's demersal trawls fisheries. Reviews in Fish Biology and Fisheries, 5(2), 213-234.

KINEKE, G. C. \& STERNBERG, R. W. 1995. Distribution of fluid muds on the Amazon continental shelf. Marine Geology, 125(3-4), 193-233, DOI: https://doi.org/10.1016/0025-3227(95)00013-O
KLAUTAU, A. G. C. M., CORDEIRO, A. P. B., CINTRA, I. H. A., SILVA, L. E. O., BASTOS, C. E. M., CARVALHO, H. R. L. \& ITÓ, L. S. 2016. Analysis of the Industrial Fishing of Piramutaba Catfish, Brachyplatystoma vaillantii (Valenciennes 1840), in two Estuarine Areas of the Brazilian Amazon. Pan-American Journal of Aquatic Sciences, 11(2), 143-150.

LENTZ, S. J. 1995a. Seasonal variations in the horizontal structure of the Amazon Plume inferred from historical hydrographic data. Journal of Geophysical Research: Oceans, 100(C2), 2391-2400, DOI: https://doi.org/10.1029/94JC01847

LENTZ, S. J. 1995b. The Amazon River Plume during AMASSEDS: subtidal current variability and the importance of wind forcing. Journal of Geophysical Research: Oceans, 100(C2), 2377-2390, DOI: https://doi. org/10.1029/94JC00343

LEWISON, R. L., CROWDER, L. B., READ, A. J. \& FREEMAN, S. A. 2004. Understanding impacts of fisheries bycatch on marine megafauna. Trends in Ecology \& Evolution, 19(11), 598604, DOI: https://doi.org/10.1016/j.tree.2004.09.004

LOWE-MCCONNELL, R. H. 1962. The fishes of the British Guiana continental shelf, Atlantic coast of South America, with notes on their natural history. Zoological Journal of the Linnean Society, 44(301), 669-700, DOI: https://doi. org/10.1111/j.1096-3642.1962.tb01964.x

MAIA, B. P., NUNES, Z. M. P., HOLANDA, F. C. A. F., SILVA, V. H. S. \& SILVA, B. B. 2016. Gradiente latitudinal da beta diversidade da fauna acompanhante das pescarias industriais de camarões marinhos da costa Norte do Brasil. Biota Amazônia, 6(1), 31-39.

MARCENIUK, A. P., CAIRES, A. R., WOSIACKI, W. B. \& DARIO, F. D. 2013. Conhecimento e conservação dos peixes marinhos e estuarinos (Chondrichthyes e Teleostei) da costa norte do Brasil. Biota Neotropica, 13(4), 251-259, DOI: https://doi. org/10.1590/S1676-06032013000400022

MARCENIUK, A. P. \& FERRARIS C. J. 2003. Family Ariidae (Sea catfishes). Check list of the freshwater fishes of South and Central America. Porto Alegre: EDIPUCRS.

MARTINS, D. E. G., ZORRO, M. C., SOUZA FILHO, P. W., CINTRA, I. H. A. \& SILVA, K. C. A. 2015. Spatial distribution of southern brown shrimp (Farfantepenaeus subtilis) on the Amazon continental shelf: a fishery, marine geology and GIS integrated approach. Brazilian Journal of Oceanography, 63(4), 397-406, DOI: https://doi.org/10.1590/S167987592015090106304

MARTINS, I. M., MEDEIROS, R. P., DI DOMENICO, M. \& HANAZAKI, N. 2018. What fishers' local ecological knowledge can reveal about the changes in exploited fish catches. Fisheries research, 198, 109-116, DOI: https://doi.org/10.1016/j. fishres.2017.10.008

MASSON, S. \& DELECLUSE, P. 2001. Influence of the Amazon River runoff on the tropical Atlantic. Physics and Chemistry of the Earth, Part B: Hydrology, Oceans and Atmosphere, 26(2), 137-142, DOI: https://doi.org/10.1016/S14641909(00)00230-6

MOLLERI, G. S., NOVO, E. M. D. M. \& KAMPEL, M. 2010. Spacetime variability of the Amazon River plume based on satellite ocean color. Continental Shelf Research, 30(3-4), 342-352, DOI: https://doi.org/10.1016/j.csr.2009.11.015 
MOURA, R. L., AMADO-FILHO, G. M., MORAES, F. C., BRASILEIRO, P. S., SALOMON, P. S., MAHIQUES, M. M., BASTOS, A. C., ALMEIDA, M. G., SILVA JUNIOR, J. M., ARAUJO, B. F., BRITO, F. P., RANGEL, T. P., OLIVEIRA, B. C. V., BAHIA, R. G., PARANHO, R. P., DIAS, R. J. S., SIEGLE, E., FIGUEIREDO JUNIOR, A. G., PEREIRA, R. C., PEREIRA, R. C., LEAL, C. V., HADJU, E., ASP, N. E., GREGORACCI, G. B., NEUMANN-LEITÃO, S., YAGER, P. L., FRANCINI-FILHO, R. B., FRÓES, A., CAMPEÃO, M., SILVA, B. S., MOREIRA, A. P. B., OLIVEIRA, L., SOARES, A. C., ARAUJO, L., OLIVEIRA, N. L., TEIXEIRA, J. B., VALLE, R. A. B., THOMPSON, C. C., REZENDE, C. E. \& THOMPSON, F. L. 2016. An extensive reef system at the Amazon River mouth. Science Advances, 2(4), e1501252, DOI: https://doi.org/10.1126/sciadv.1501252

MULLER-KARGER, F. E., MCCLAIN, C.R. \& RICHARDSON, P. L. 1988. The dispersion of the Amazon's water. Nature, 333(6168), 56-59, DOI: https://doi.org/10.1038/333056a0

NASCIMENTO, M. C., AMARAL, A. C. Z. \& CANZIANI, G. V. 2009. Análise e modelagem das interações tróficas de peixes demersais no Sudeste-Sul do Brasil [online]. São Lourenço: Anais do III Congresso Latino Americano de Ecologia. Available at: http://repositorio.furg.br/bitstream/handle/1/5603/An\%E1lise\%20e\%20modelagem\%20das\%20 intera $\%$ E7\%F5es $\% 20$ tr\%F3ficas $\% 20$ de\%20 peixes $\% 20$ demersais $\% 20$ no\%20Sudeste-Sul\%20do\%20Brasil. pdf? sequence $=1$ [Accessed: 19 May 2020].

NITTROUER, C. A., KUEHL, S. A., DEMASTER, D. J. \& KOWSMANN, R. O. 1986. The deltaic nature of Amazon shelf sedimentation. Geological Society of America Bulletin, 97(4), 444-458, DOI: https://doi.org/10.1130/0016-7606(1986)97<444:TDN OAS> 2.0.CO;2

NÓBREGA, P. S. V. D., SANTOS, C. R. M. D., CORDEIRO, A. P. B. \& MARTINELLI-LEMOS, J. M. 2021. Invertebrates assemblage captured by a pink shrimp's fishery on Amazon continental shelf. Latin American Journal of Aquatic Research, 49(2), 227-241, DOI: http://dx.doi.org/10.3856/vol49-issue2-fulltext-2600

OLIVEIRA, G. M., BARROS, A. C., EVANGELISTA, J. E., SANTOS, A. R. B., HAIMOVICI, H. \& FISHER, L. G. 2007. Prospecção na Região Norte. A prospecção pesqueira e a abundância de estoques marinhos no Brasil nas décadas de 1960 a 1990. Brasília: IBAMA (Instituto Brasileiro do Meio Ambiente e dos Recursos Naturais Renováveis).

PASSOS, C. V. B., FABRÉ, N. N., MALHADO, A. C. M., BATISTA, V. S. \& LADLE, R. J. 2016. Estuarization increases functional diversity of demersal fish assemblages in tropical coastal ecosystems: estuarization and functional diversity. Journal of Fish Biology, 89(1), 847-862, DOI: http://dx.doi.org/10.1111/ jfb.13029

PAULY, D., ALDER, J., BENNETT, E., CHRISTENSEN, V., TYEDMERS, P. \& WATSON, R. 2003. The future for fisheries. Science, 302(5649), 1359-1361, DOI: https://doi.org/10.1126/science. 1088667

PAULY, D., CHRISTENSEN, V., GUENETTE, S., PITCHER, T. J., SUMAILA, U. R., WALTERS, C. J., WATSON, R. \& ZELLER, D. 2002. Towards sustainability in world fisheries. Nature, 418, 689-695, DOI: https://doi.org/10.1038/nature01017

PERILLO, G. M. E., PICCOLO, M. C. \& PINO QUIVIRA, M. 1999. What do we know about the geomophology and physical oceanography of South American estuaries? In: PERILLO, G. M. E., PICCOLO, M. C. \& PINO QUIVIRA, M. (eds.). Estuaries of South America: their geomophology and dynamics. Berlin: Springer Verlag, pp. 1-13.
PINHEIRO, L. A. \& FRÉDOU, F. L. 2004. Caracterização geral de pesca industrial desembarcada no estado do Pará. Revista Científica da Universidade Federal do Pará, 4(1), 1-16.

RYBARCZYK, H. \& ELKAÏM, B. 2003. An analysis of the trophic network of a macrotidal estuary: The Seine Estuary (Eastern Channel, Normandy, France), Estuarine, Coastal and Shelf Science, 58(4), 775-791, DOI: https://doi.org/10.1016/S02727714(03)00184-7

SILVA, L. E. O., SILVA, K. C. A. \& CINTRA, I. H. A. 2014. Sobre a pesca industrial para peixes diversos na Plataforma Continental Amazônica. Revista Brasileira de Engenharia de Pesca, 7(2), 34-53.

STILES, M. L., STOCKBRIDGE, J., LANDE, M. \& HIRSHFIELD, M. F. 2010. Impacts of Bottom Trawling on Fisheries, Tourism, and the Marine Environment [online]. Belize City: Oceana Central America. Available at: https://oceana.org/reports/impacts-bottom-trawling-fisheries-tourism-and-marine-environment [Accessed: 18 May 2020].

STOBUTZKI, I. C., MILLER, M. J., JONES, P. \& SALINI, J. P. 2001. Bycatch diversity and variation in a tropical Australian penaeid fishery; the implications for monitoring. Fisheries Research, 53(3), 283-301, DOI: https://doi.org/10.1016/ S0165-7836(00)00273-3

SZPILMAN, M. 2000. Peixes marinhos do Brasil: guia prático de identificação. Rio de Janeiro: Instituto Ecológico Aqualung.

TAYLOR, W. R. \& MENEZES, N. A. 1978. FAO species identification sheets for fishery purposes. West Atlantic (Fishing Area 31). Ariidae. Rome: FAO Fisheries Department.

TONKS, M. L., GRIFFITHS, S. P., HEALES, D. S., BREWER, D. T. \& DELL, Q. 2008. Species composition and temporal variation of prawn trawl bycatch in the Joseph Bonaparte Gulf, northwestern Australia. Fisheries Research, 89(3), 276-293, DOI: https://doi.org/10.1016/j.fishres.2007.09.007

UNEP (United Nations Environment Programme). 2011. Towards a green economy: pathways to sustainable development and poverty eradication [online]. Nairobi: UNEP. Available at: www.unep.org/greeneconomy [Accessed: 13 July 2020].

VENDEVILLE, P. \& BAUDRIER, J. 2006. Étude des peuplements de juvéniles de Poissons et de crevettes des fonds du littoral de Guyane [online]. Guyane: Département Halieutique Méditerranéenne et Tropicale Station de Guyane Laboratoire Ressources Halieutiques de Guyane. Available at: https://archimer.ifremer. fr/doc/00074/18527/16070.pdf [Accessed: 18 August 2020].

VILAR, C., JOYEUX, J., GIARRIZZO, T., SPACH, H., VIEIRA, J. P. \& VASKE-JUNIOR, T. 2013. Local and regional ecological drivers of fish assemblages in Brazilian estuaries. Marine Ecology Progress Series, 485, 181-197, DOI: https://doi.org/10.3354/meps10343

WILLEMS, T., DE BACKER, A., MOL, J. H., VINCX, M. \& HOSTENS, K. 2015 a. Distribution patterns of the demersal fish fauna on the inner continental shelf of Suriname. Regional Studies in Marine Science, 2, 177-188, DOI: https://doi.org/10.1016/j.rsma.2015.10.008

WILLEMS, T., DE BACKER, A., YOU, K. W. T., VINCX, M. \& HOSTENS, K. 2015b. Spatio-temporal distribution patterns of the epibenthic community in the coastal waters of Suriname. Continental Shelf Research, 108, 25-40, DOI: https://doi. org/10.1016/j.csr.2015.08.006

WOLFF, M., KOCH, V. \& ISAAC, V. 2000. A trophic flow model of the Caeté Mangrove estuary (North Brazil) with considerations for the sustainable use of its resources. Estuarine, Coastal and Shelf Science, 50(6), 789-803, DOI: https://doi. org/10.1006/ecss.2000.0611 